\title{
REVITALISASI PENDIDIKAN RUHANI DALAM RANGKA MENCEGAH PENYALAHGUNAAN NARKOBA PADA PELAJAR
}

\author{
Muhamad Arif* dan Mei Kalimatusyaro \\ STAI Al-Azhar Menganti, Indonesia \\ IAI Al-Khoziny Sidoarjo, Indonesia \\ *E-mail:arif@stai-ala々barmenganti.ac.id
}

\begin{abstract}
The strength of spirituality in a person becomes an alternative in preventing the high of drug abuse among students. This research was carried out at Al-Azhar Menganti Vocational High School under the auspices of the Darul Ihsan Menganti Islamic Boarding School Foundation. This study uses a qualitative method with a case study approach. Data collection technique uses observation, interviews and documentation. The validity test of the data uses theory of Miles and Hubarman. The research's results showed that the application of spiritual education carried out at Al-Azhar Vocational School in Menganti, namely with the pattern of contemporary spiritual education, aroused interest of students in learning it. Whereas in coping with its obstacles school has overcome several breakthroughs, such as: strengthening cooperation between schools, teachers, and parents with Islamic eduparenting.
\end{abstract}

Keywords: Spiritual education, Drugs, Students

\begin{abstract}
Abstrak. Kekuatan spiritulitas pada diri seseorang menjadi alternatif dalam mencegah tingginya penyalahgunaan narkoba pada pelajar. Penelitian ini dilakukan pada Sekolah Menengah Kejuruan Al-Az̧bar Menganti yang berada di bawah naungan Yayasan Pondok Pesantren Darul Ihsan Menganti. Penelitian ini menggunakan metode kualitatif dengan pendekatan studi kasus. Teknik pengumpulan data dengan menggunakan, observasi, wawancara dan dokumentasi, serta uji keabsaban data menggunakan teori dari Miles dan Hubarman. Hasil penelitian menunjukean bahwa penerapan pendidikan rubani yang dilakukan pada SMK Al-Azhar Menganti, yaitu dengan pola pendidikan rubani kontemporer, menimbulkan minat pelajar dalam mempelajarinya. Sedangkan dalam mengatasi hambatannya sekolah sudah menanggulangi dengan beberapa terobosan, seperti: penguatan kerjasama antara sekolah, guru, dan orang tua dengan eduparenting Islami.
\end{abstract}

Kata Kunci: Pendidikan Rubani, Narkoba, Pelajar 


\section{PENDAHULUAN}

Pendidikan adalah sebagai usaha sadar yang dilakukan dari seorang kepada orang lainnya dengan kurun waktu tertentu. Pendidikan juga sebagai transformasi ilmu pengetahuan, budaya dan nilai-nilai yang berkembang pada suatu generasi agar dapat disalurkan kepada generasi berikutnya. Pada dasarnya pendidikan secara luas mengarahkan manusia pada perwujudan budaya yang mengarahkan pada perkembangan masyarakat. Hasan Langgulung, mendefinisikan pendidikan sebagai usaha transfor-masi keilmuan dari orang yang di anggap mempunyai keahlian pada bidangnya kepada orang lain.(Suryadi, 2018, pp. 1-3) Sedangkan dalam pendidikan islam mempunyai tujuan yang mengarah pada pengembangan aktualisasi dari dalam kehidupan bermasyarakat. Serta lebih menempatkan manusia sebagai makluk Allah yang mampu mengikuti perkembangan zaman, manusia sebagai obyek sekaligus subyek pendidikan yang tidak bebas nilai. Karena pada hakikatnya nilai-nilai terkandung pada penciptanNya. Karena disitulah tujuan dari pendidikan Islam sebagai salah satu wadah untuk mentransformasi nilai ajaran islam, seperti berbudi luhur dan mempunyai akhlak mulia, serta mendapatkan kebahagiaan yang bermakna (n.d., pp. 59-60).

Berpijak pada tujuan pendidikan Islam di atas dapat di ambil garis lurus, bahwa pengetahuan dalam dunia Islam lebih bersifat aksiologi, yang berfungsi mengkontruksi fakta, karena islam tidak berkehendak memisahkan antara ilmu dan nilai seperti halnya barat.
Karena ilmu adalah hasil dialog para ilmuan dengan realitas yang terjadi pada masanya. Sedangkan Islam meletakkan wahyu sebagai paradigma agama yang mengakui eksistensi tuhan, tidak hanya sebatas keyakinan. Tetapi menerapkan sebagai kontruksi ilmu pengetahuan.(Qomar, 2013, pp. 3233) Maka dari itu dalam pendidikan Islam, mempunyai tujuan yang jelas, seperti: pembentukan akidah yang benar bagi manusia, Pengajaran ibadah yang benar, menumbuhkan keinginan saling mengenal sesama manusia, menyebarkan spirit kerjasama di antara manusia, bekerja untuk memakmurkan negeri, dan mengajari manusia tentang bagaimana berkomitmen dalam hidup.(Al-Kattani, Dkk., n.d., pp. 2731) Pada dasarnya tujuan pendidikan islam tidak dapat di pisahkan dengan Pendidikan ruhani (at-Tarbiyah arRubiyyah) sebagaimana pemaparan dari Abd. Al-Rahman Shalih Abd Allah, tentang tujuan pendidikan islam, dalam bukunya education Theory, a Quranic Outlook, menjelaskan tentang pendidikan Islam meliputi: pendidikan jasmani, pendidikan ruhani, pendidikan akal dan pendidikan sosial.(Suryadi, 2018, pp. 51-54)

Pendidikan Ruhani adalah, sebuah pendidikan yang memadukan antara hati, jiwa, akal dan ruh, secara bersamaan dan terintegrasi sebagaimana pemaparan dari Zakaria Dkk. Menjelaskan bahwa seluruh pendidikan dalam islam merujuk pada pendidikan ruhani, membentuk manusia sebagai seorang hamba yang memancarkan kejernihan akhlak yang baik dan budi pekerti yang tinggi tanpa melanggar nilai-nilai islam yang tertulis dalam alQur'an dan Hadis.(Stapa et al., 2012) 
Hal senada juga di sampaikan oleh Zuhri, bahwa tujuan dari pendidikan ruhani adalah meningkatkan jiwa, dan kesetiaan hanya kepada Allah semata, serta meneladani moralitas islam yang di contohkan oleh Nabi Muhammad dengan berdasarkan al-Qur'an dan hadis.(2016b, p. 127) Melihat pentingnya kebradaan pendidikan ruhani, maka sudah seharusnya dapat di tanamkan pada seseorang sedini mungkin, baik dalam lingkungan keluarga, dunia pendidikan baik formal dan non formal. Karena pendidikan ruhani dapat menjadi tolak ukur moralitas seseorang dalam menjalani kehidupan.

Beberapa fakta di Indonesia yang cukup mencengangkan tentang maraknya penggunaan narkoba justru di dominasi oleh generasi muda, terutama dalam lingkup sekolah yaitu para pelajar, yang sejatinya mereka berlomba-lomba belajar dengan giat dalam menngapai cita-cita di masa depan. Namun, para pelajar terkotak dalam dunia hitam dan terkontaminasi dengan barang-barang yang dilarang untuk di kosumsi (narkoba). Narkoba adalah singkatan dari Narkotika, Psikotropika dan bahan adiktif berbahaya lainnya. Kata narkotika berasal dari yunani yaitu "narkom" yang mempunyai arti membuat lumpuh dan mati rasa. Karena narkotika sendiri sebuah zat yang di ambil dari tanaman atau bukan tanaman. Baik sinteisis maupun semisintesis, yang dapat menyebabkan penurunan, hilangnya rasa nyeri, ketenangan dan yang berbahaya adalah menimbulkan ketergantungan.(Taringan, n.d., p. 4)

Merespon maraknya penyalahgunaan narkoba di Negara Indonesia, maka pemerintah melakukan langkah pencegahan, memberantas penyalahgunaan narkoba dan peredaran gelap narkotika. Dengan membentuk Badan Narkotika Nasional (BNN) pada tahun 2002 dari hasil keputusan presiden, yang kemudian di ganti dengan pereturan presiden nomor 83 pada tahun 2007. Dari sinilah terungkap banyak fakta tentang penyalagunaan narkotika pada tahun 2019. Sebagaimana pemapran Komjen Pol Heru Winarko di Tribun News yang meyatakan bahwa dari tahun 2017-2018 Penggna narkoba, di dominasi oleh generasi muda (pelajar). "Prosentase 1,77 persen sementara pada tahun ini naik. Tahun kemaren kerjasam dengan FK UI, tahun ini kerja sama dengan LIPI, dan tahun ini meningkat 2,1 persen.” (http://www.tribunnews.com/nasiona l/2018/12/20/bnn-sepanjang-tahun2018-mayoritas-pengguna-narkobaadalah-generasi-muda), dari data tersebut maka sangat terlihat bahwa Peran sekolah sangatlah dibutuhkan dalam mencegah tingginya penyalahgunaan narkoba pada pelajar.

Beberapa hasil penelitian tentang penyalahgunaan narkoba cukuplah mendominasi, sebagaimana Hasil penelitian Ahmad Syafi'I tentang pengaruh narkoba terhadap kenakalan remaja di Sulawesi tengah. Hasil menunjukkan bahwa penggunaan narkoba pada usia remaja dilakukan karena dua faktor, faktor internal yang meliputi, 1) rasa ingin tahu dari remaja tentang narkoba, 2) minimnya pendidikan agama, 3) Menghilangkan stress 4) Frustasi, dll. Sedangkan faktor eksternal meliputi, 1) faktor keluarga (kurang perhatian dan kasih sayang), 
broken bome 2) faktor kesalahan dalam memilih teman. Dari faktor di atas berdampak pada kenakalan remaja yang mengarah pada meningkatnya tindakan kriminalitas seperti, pencurian, perampokan, tawuran bahkan pembunuhan.(Syafii, 2009) Sejalan dengan hasil penelitian Ahmad Syafi'I, hasil penelitian dari Elviza Rahmadona dan Helfi Agustin tentang faktor yang berhubungan dengan penyalahgunaan narkoba di RSJ Prof. HB. Sa'anin Kota Padang mendapatkan hasil bahwa, lebih dari separuh penyalahgunaan narkoba dikarenakan responden memiliki tingkat religious yang rendah $(56,9 \%)$, sedangkan faktor dari keluarga yang kurang baik dalam pencegahan penggunaan narkoba $(41,7 \%)$, dan dominasi terbanyak dalam penyalahgunaan narkoba adalah teman yang tidak baik sekitar (70,8\%) (Rahmadona \& Agustin, 2014).

Bertolak dari faktor penyalahgunaan narkoba dan pengaruhnya, terdapat hasil penelitian tentang upaya pencegahan dan pengobatan bagi pengguna narkoba. Sebagaimana hasil penelitian Maryatul Kibtiyah, dengan menggunakan pendekatan pendidikan dan konseling Islam, yang meliputi perawatan medis, psikis, mental dan spiritual bagi korban pengguna narkoba, adalah salah satu solusi yang dapat digunakan. Namun, hasil penelitian ini sangat membutuhkan sumbangsih para pakar yang kompeten dalam bidang sosial, moral dan spiritual.(Kibtyah, 2017) Hasil penelitian Elrick Christovel Sanger, tentang penegakan hukum terhadap peredaran narkoba di kalangan generasi muda, menggaris bawahi bahwa dalam pencegahan penyalah- gunaan narkoba, lebih menitik beratkan pada kolaborasi antara masyarakat dan pihak sekolah serta didukung dengan media masa, baik media cetak dan media elektronik agar dapat digunakan dengan semaksimal mungkin dalam memberikan informasi kepada generasi muda.(Sanger, 2013)

Dari pemaparan beberapa hasil penelitian, peneliti semakin tergelitik, untuk melakukan riset secara mendalam. Karena salah satu titik tumpuh dan saran dari beberapa penelitian di atas adalah kekuatan spiritulitas seseorang menjadi tolak ukurnya. Pada penelitian ini, sekolah memberikan alternatif dalam mencegah tingginya penyalahgunaan narkoba pada pelajar, yaitu dengan menggunakan pendidikan ruhaniah (spiritual). Penelitian ini dilakukan di SMK al-Azhar Menganti Gresik, yang notabenya Sekolah Menengah Kejuruan berada di bawah naungan Yayasan Pondok Pesantren Darul Ihsan Menganti. Salah satu sekolah yang menjadi cerminan sekolah sekitar karena tidak ada satupun siswa-siswa yang menjadi korban penyalahgunaan narkoba. Karena salah satu keunikannya di sekolah ini adalah, pendidikan ruhani yang diberikan kepada semua siswa SMK al-Azhar Menganti setiap sebelum memulai pelajaran, yaitu dengan berkumpul di lapangan, dengan tema "mengetuk pintu langit", di dalamya siswa di ajak untuk, berdzikir, bersholawat dan berdoa bersama kepada Allah dengan tenang dan khusyuk. Sebagai salah satu upaya menguatkan ruhaniah peserta didik kepada sang pencipta. Dari hasil observasi inilah peneliti ingin mendalami keunikannya yaitu Dengan 
menitik fokuskan tentang Bagaimana penerapan pendidikan ruhani dalam mencegah tingginya kasus penyalahgunaan narkoba pada peserta didik di SMK Al-Azhar Menganti Gresik, dan Apa saja faktor penghambat dalam menerapkan pendidikan ruhani di SMK Al-Azhar Menganti Gresik.

\section{METODE PENELITIAN}

Berpedoman dari hasil observasi di atas, maka penulis semakin ingin melakukan riset secara spesfik di SMK al-Azhar Menganti Gresik, yang berada pada naungan pondok pesantren. Dengan judul Revitalisasi Pendidikan Ruhani dalam Mencegah Penyalahgunaan Narkoba pada Pelajar (Studi Kasus SMK Al-Azhar Menganti Gresik). Menggunakan pendekatan kualitatif studi kasus,(Arif, 2018) Objek penelitian ini, adalah sebuah sekolah menengah kejuruan berbasis pesantren yang digunakan untuk mencari dan mendapatkan data yang diperlukan selama kegiatan penelitian berjalan. Penelitian di Sekolah Menengah Kejuruan (SMK) al-Azhar Menganti Gresik. Waktu yang digunakan dalam penelitian ini adalah setelah melakukan observasi awal pada 21 Desember 2019 sampai 7 Februari 2020. Metode pengumpulan data yang digunakan dalam penelitian ini, menggunakan tiga metode yaitu meliputi: a) Metode observasi.(2016a, p. 66) b) wawancara tak terstruktur, dan c) metode dokumentasi.(2016a, pp. 79-82). Ketiga metode di atas di gunakan untuk mencari data terkait dengan penerapan pendidikan ruhani serta faktor penghambatnya. Sedangkan teknik analisis data dari
Miles dan Hubarman yang menggunakan tiga pendekatan, yaitu: a) Data kondensasi, b) display data dan c) verifikasi dan penarikan kesimpu-lan (Arif \& Sulistianah, 2019). Setelah melakukan analisis data, peneliti melakukan uji keabsahan data menggunakan triangulasi data, yang meliputi 2 cara, seperti yang akan disebutkan di bawah ini:.(Wijaya, 2018, pp. 120-121) a) Triangulasi sumber: Sebuah cara menguji data yang di peroleh dari hasil pengumpulan data, dengan cara menguji dari beberapa sumber yang berbeda-beda, namun menggunakan metode yang sama. Seperti contoh: menguji perolehan hasil pengumpulan data, dari kepada kepala sekolah, wakil kepala sekolah, waka kurikulum, namun menggunakan satu metode yang sama, yaitu wawancara.(2010, p. 76) b) Trangulasi metode: Sebuah cara yang di pakai peneliti dalam mengecek kreadibilitas data, dari hasil penelitian. Dalam praktik teriangulasi metode adalah dengan menggunakan metode yang berbeda namun sumber yang sama. Seperti contoh uji keabsahan data hasil dari menggunakan metode wawancara, observasi dan dokumentasi namun dengan satu sumber yang sama yaitu kepala sekolah.(2016a, p. 84)

\section{HASIL PENELITIAN DAN PEMBAHASAN} Penerapan Pendidikan Ruhani
dalam Mencegah Tingginya
Kasus Penyalahgunaan Nar-
koba Pada Peserta Didik di
SMK Al-Azhar Menganti Gresik 
Narkoba pada dasarnya adalah hanya sebagai istilah, bukan sebuah nama dari obat-obatan. Narkotika (Nar), Psikotropika (Ko), dan Bahan adiktif (Ba), selain itu Narkoba juga mempunyai kepanjangan Napza (Narkotika, Psikotropika dan Zak adiktif) (Amriel, 2007, p. 6). Narkotika juga di jelaskan secara rinci pada UU No.22 Tahun 1997, bahwa narkotika adalah sebuah zat yang berasal dari tanaman, atau bukan tanaman baik sintesis maupun semi sintesis yang dapat menyebabkan perubahan kesadaran, hilangnya rasa, mengurangi sampai menghilangkan rasa nyeri, dan dapat menimpulkan ketergantungan pada diri pemakai. Sedangkan psikotropika adalah sebuah obat atau zat, alamiah maupun sintesis bukan narkotika, yang mempunyai khasiat psikoaktif melalui pegaruh selektif pada saraf pusat sehingga menimbulkan perubahan khas pada aktivitas prilaku dan mental pemakai. Sedangkan bahan adiktif lainnya adalah sebuah zat atau bahan lainnya bukan narkoba dan psikotropika yang dapat berpengaruh secara signifikan pada kerja otak dan dapat menimbulkan ketergantungan. Dapat difahami bahwa tidak semua jenis narkotika dan psikotropika dilarang penggunaanya. Karena terdapat banyak narkotika dan psikotropika yang bermanfaat pada bidang kedokteran serta untuk kepentingan pengembangan ilmu pengetahuan.(Kibtyah, 2017) Beberapa Penerapan pendidikan ruhani dalam mencegah tingginya kasus penyalahgunaan narkoba pada peserta didik di SMK al-Azhar Menganti Gresik, sebagaimana beberapa hasil wawancara di bawah ini:
Hasil wawancara dengan kepala sekolah SMK al-Azhar Bpk. Akhmad Ihksan memaparkan tentang penerapan pendidikan ruhani dalam mencegah tingginya kasus penyalahgunaan narkoba pada peserta didik di SMK Al-Azhar Menganti Gresik, sebagai berikut:

"Penerapan pendidikan ruhani di SMK Al-Azhar Menganti terbagi menjadi beberapa bagian: 1) Pihak sekolah mengadakan kegiatan keagamaan yang mendidik pada ruhani siswa dalam tempo sesering mungkin seperti: pada setiap pagi sebelum siswa masuk kedalam kelas, mereka di ajak untuk bermunajat, malantunkan sholawat, dzikir dan dilanjutkan dengan sholat dhuha berjama'ah. Agar siswa mendapatkan ketenangan dalam belajar dan menjalani hidup, karena banyak siswa yang masuk lingkaran narkobakan mereka tidak mendapat ketenangan, akhirnya kosumsi narkoba dengan alasan mencari ketenganan

Mendatangkan tokoh kyai sekitar berkolaborasi dengan BNN, Polri dan TNI untuk memberikan siraman ruhani sesering mungkin sebagai bentuk perhatian yg berimbang terhadap pengaruh luar yg demikian hebat, seperti materi bahaya penyalahgunan narkoba disandingkan dengan materi kajian fikih islam terkait hukum dari narkoba dan sejenisnya. Selain pendidikan ruhani kepada siswa. 3) Sekolah mempunyai terobosan dengan Mendatangkan orang tua melalui program eduparenting islami minimal 4 kali setahun. Secara 
dhohir kegiatan ini nampak bukan kegiatan Ruhani. Namun tujuan utama adalah menguatkan ruhani orang tua dan siswa. Agar terjalin visi dan misi yang sama dalam menuntut ilmu. Serta memberikan pendidikan terhadap orang tua bahwa semua yang ada di SMK Al Azhar bukan hanya siswa, tapi orang tua dan guru juga belajar. Guru belajar untuk mengamalkan ilmu dan mendalami kondisi siswa dan orangtua sehingga tahu realita masing-masing siswa, sementara orangtua belajar bagaimana mendidik anak bersama pihak sekolah dan cara memperlakukan anak sesuai dengan fitrahnya serta menunjukkan sesuatu yang dilarang oleh aturan sekolah, seperti: tidak masuk sekolah tanpa izin, tawuran, minum-minuman keras, merokok, kosumsi narkoba, dll. Karena kesuksesan seorang siswa tidak dapat dijamin 100\% oleh sekolah, atau bahkan siswa, maka dari itu Orangtua diharapkan membantu, mendamping dan mendorong untuk menghantarkan menuju kesuksesan melalui mendekatkan diri kepada Allah, berdo'a, amal Sholeh, menjaga kehalalan makanan, minuman, pakaian dll. untuk mempermudah anak dalam mendapatkan ilmu yang bermanfaat. 4) Menjalin kerjasama dengan pihak pesantren dari berbagai lini pendidikan, karena terbilang satu-satunya pendidikan yang tidak tersentuh dengan barang-barang terlarang hanya pesantren(Wawancara, 17 Januari 2020).

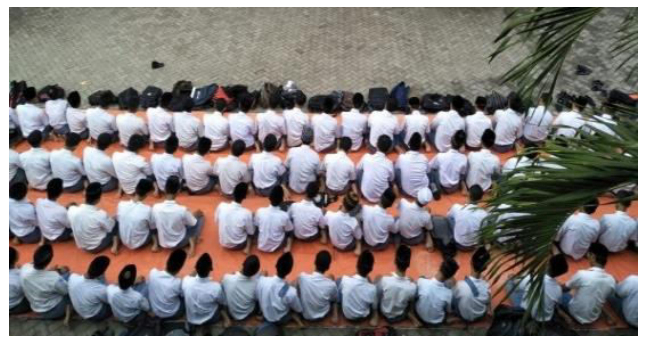

Gambar: 1.1: Sholat dhuha berjamaah sebelum KBM di mulai

Sebagaimana pemaparan dari kepala sekolah, pemaparan senada di sampaikan oleh wakil kepala sekolah, Bpk. Nur Qomari tentang Penerapan pendidikan ruhani dalam mencegah tingginya kasus penyalahgunaan narkoba pada peserta didik di SMK AlAzhar Menganti Gresik, sebagai berikut:

"Dalam rangka pencegahan terhadap tingginya peserta didik dalam penyalahgunaan narkoba, sekolah kami membuat penguatan pada pendidikan ruhani anakanak, karena selama ini mereka para pelajar menyalah gunakan biasanya karena ingin mencari ketenagan, anak muda, kadang putus sama pacar atau ada masalah ketika di rumah, mereka melampiaskan dengan mengkonsumsi narkoba, alasanya biar tenang. Jadi, kalau di sekolah kami, 1) Siswa di arahkan setiap pagi, datang di sekoalah di sambut dengan lantunan sholawat, seperti sholawat nariyah, sholawat nahdliyin, dan sholawat lainnya. Ketika siswa sudah lengkap kita melakukan sholat dhuha bersama, dzikir bersama guna memberikan ketenangan pada diri siswa. Setelah itu kita adakan tausiyah keagamaan dari pihak pesantren 
sebagai penguatan pada ruhani siswa. 2) Memberikan siraman ruhani setiap selasai melakukan sholat dhuhur berjama'ah, terkait kewajiban dalam belajar serta larangan-larangan dalam belajar. Pengingat diberikan sesering mungkin agar siswa selalu terniang dalam hati dan akalnya. 3) Berkolaborasi dengan unsur pesantren dalam mengadakan kajian-kajian Islam tentang hukum dari barang yang dilarang dalam agama Islam, seperti miras, narkoba, dll. Setiap satu bulan sekali, sebagai penguat dan pengingat pada diri siswa. 4) terapi dzikir dari pihak pondok pesantren kolaborasi dengan SMK Al-Azhar Menganti Gresik (Wawancara 18 januari 2020).

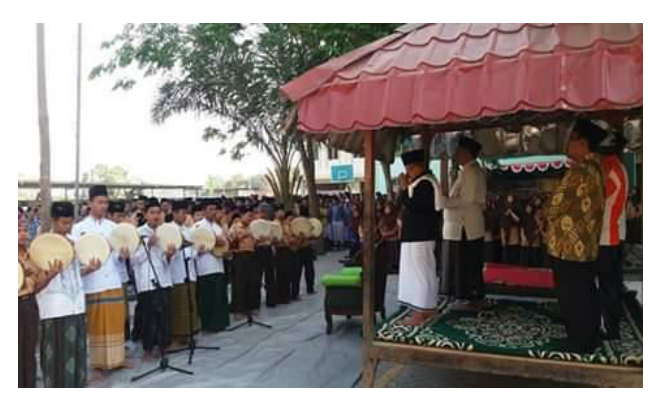

Gambar 1.2: Pembacaan sholawat, dzikir di lanjut dengan tausiyah keagamaan (Penguatan pendidikan ruhani)

Pendidikan ruhani mempunyai
peran besar dalam menguatkan kepribadian siswa di sekolah, menjadi penguat utama di SMK al-Azhar menganti, sebagaimana pemaparan dari wakil kurikulum Bpk. Mustain, yang menjelaskan:

"Keberadaan pendidikan ruhani pada sekolah kami, meliputi banyak aspek. Namun, pada dasarnya pendidikan ruhani menjadi sebuah pendidikan yang masuk pada bidden curriculum di SMK Al-Azhar Menganti Gresik. Karena pada dasarnya sudah tertata sangatlah rapi, seperti halnya 1) kegiatan kegiatan di pagi hari "mengetuk pintu langit", menjadi agenda setiap pagi di sekolah kami, dengan serangkaian acara, dari pembacaan sholawat, pembacaan dzikir, sholat dhuha berjamaah serta penguatan (tausiyah), yang berisikan tentang hukum mengkosumsi obat-obatan terlarang, miras, dll. Sebagai penutup pada setiap acara pagi. 2) Pemberlakuan nama santri pada diri siswa, adalah salah satu upaya supaya mereka mengingat dan merasa memiliki agar tidak terjerumus dalam sesuatu yang tidak pantas di lakukan, seperti: penyalahgunaan narkoba dan sejenisnya. 3) Terapi dzikir sebagai upaya dalam menyadarkan dan menjemput ketenagan pada hati, jiwa dan indra (HAI) bekerjasama dengan pihak pondok pesantren, karena info dari BNN pelajar mengkonsumsi narkoba salah satunya adalah mencari ketengan. Jadi, kita memberi solusi untuk mendapatkan ketengan tanpa mengkonsumsi yang haram. 4) Selain usahan antara siswa dan sekolah, kita pihak sekolah menjalin kerjasama dengan orang tua, dengan mengadakan eduparenting Islami sebagai upaya penyadaran bahwa siswa adalah tangung jawab bersama antara pihak sekolah yang di motori guru, dengan orang tua (segitiga 
emas: siswa, guru dan orang tua). Karena tanpa terobosan itu, terkesan siswa di pasrahkan dan harus berhasil di tangan sekolah, itu sesuatu yang nihil." (Wawancara, 18 Januari 2020).

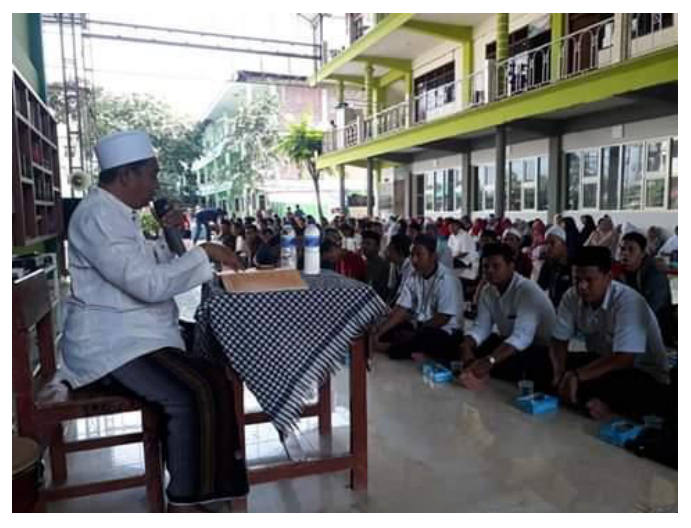

Gambar 1.3: Kerjasama dengan Pondok Pesantren dalam menguatkan kerjasama antara orang tua, siswa dan sekolah sebagai wujud pencegahan penyalahgunaan narkoba pada pelajar (materi eduparenting dan kajian kontemporer)

Dari beberapa pemaparan hasil wawancara tentang penerapan pendidikan ruhani di SMK al-Azhar Menganti Gresik, adalah sebagai upaya memberikan ketenangan dalam diri siswa serta pengertian tentang bahaya dari penyalahgunaan narkoba. dari beberapa hasil di atas dapat di ambil kesimpulan, sebagai berikut: (1) Pendidikan ruhani dibingkai dalam tema "mengetuk pintu langit" yang didalamnya terdapat beberapa kegiatan, yaitu: pembacaan sholawat, burdah, sholawat nahdliyin dll, pembacaan dzikir dan istighosah yang dilakukan setelah sholat dhuha, serta penguatan ruhani dengan siraman ruhani. (2) Kolaborasi dengan pondok pesantren, seperti mengadakan kajian- kajian keagamaan dari fikih islam tentang hukum dari barang yang dilarang dalam agama Islam, seperti miras, narkoba, dll sebagai upaya menanggulangi banyaknnya penyalahgunaan narkoba. (3) Adanya kegiatan terapi dzikir dalam mengaktifkan hati, jiwa dan indra (HAI) yang bekerjasama dengan podok pesantren. (4) Penguatan kerjasama dengan walimurid, sebagai upaya penanggulangan dalam penyalahgunaan narkoba pada pelajar di tengah masyarakat, dengan nama kegiatan eduparenting islami. Upaya-upaya ini menjadi sebuah terobosan baru dalam dunia pendidikan. Sebagaimana pemaparan Syafi'I tentang ketidak harusan bergantung pada guru Bimbingan konseling (BK) namun sekolah harus mampu memberikan terobosan baru dalam menangkal maraknya penyalahgunaan narkoba (Syafii, 2009).

Beranjak dari sini pastilah dapat difahami, bahwa penyalahgunaan narkoba pada pelajar sudah sepatutnya di tanggulangi secepat mungkin sebagaimana data dari Komisi Perlindungan Anak Indonesia (KPAI) dan BNN menunjukkan 5,9 juta anak Indonesia adalah pecandu narkoba (Okezone, n.d.). Dari pemaparan tentang bahaya narkoba, terdapat beberapa tempat dalam peredaran narkoba yang cukup familiar, diantaranya yaitu: 1) Lingkungan keluarga, keluarga yang broken bome menjadi sebuah tempat yang sangat subur untuk peredaran narkoba. Karena adanya kekecewaan dari beberapa pihak, terutama pada anak, yang kurang kasih sayang, serta tidak menemukan ketentraman di dalam 
keluarga. 2) Lingkungan pendidikan, diantaranya seperti di sekolah, kampus, lembaga pendidikan, atau bahkan masuk pada lembaga pendidikan berbasis keagamaan. Praktek penyalahgunaan di lembaga pendidikan di dominasi karena kurangnya perhatian dari beberpa pihak di dalamnya. Namun sekolah yang mengedepankan pencegahan dengan beberapa cara akan lebih meminimalkan pengedar narkoba di dalamnya. 3) Lingkungan kerja, pabrik, kantor, tempat hiburan, dll. Menjadi tempat bebas yang aturannya cenderung longgar. Dan inilah yang beakibat suburnya peyalahgunaan narkoba. 4) Lingkungan masyarakat, seperti terminal, bandara, hotel. Adalah sarang tersubur dalam peredaran narkoba dikarenakan sulitnya pendeteksi para pengedar narkoba (Darman, 2006, pp. 17-19).

Penyalahgunaan serta pereda-ran narkoba tidak hanya di hadapi oleh Negara Indonesia, seperti halnya Negara India juga memasukkan larangan peredaran dalam sebuah aturan pemerintah pada tahun 1930, dan Di bawah Konvensi Geneva Dangerous Drugs tahun 1925, pemerintah India merasakan tekanan diplomatik untuk mengadopsi undangundang yang kompeten untuk membatasi pembuatan, perdagangan dan konsumsi opium dan obat-obatan terlarang lainnya di wilayah tersebut:

"During the early 1930s the government of India introduced assorted legislation that failed to stamp out the abuse of drugs in South Asia. In an attempt to satisfy international demands, the government of India adopted the Dangerous Drugs Act of 1930, and treated it as a landmark in the bistory of anti-drug legislation in India. Under the Geneva Dangerous Drugs Convention of 1925, 102 the government of India felt diplomatic pressure to adopt competent laws to limit the manufacture, trade and consumption of opium and other injurious drugs in the region." (Emdad-ul Haq, 2010, p. 100)

Pada dasarnya, larangan dalam penyalahgunaan narkoba bukanlah tanpa sebab, bahaya dari penyalahgunaan narkoba yang digunakan tanpa adanya ketentuan dari para ahli, karena narkoba akan menjadi mesin perusak yang sangat mematikan, serta efek yang ditimbulkan dari penggunaan narkoba tidak hanya satu dua minggu, melainkan seterusnya sebelum terjadinya pegobatan secara intensif.(Aztri \& Milla, 2013)

Maka dari itu perlu pencegahan dari penyalahgunaan narkoba dapat di tanggulangi melalui beberapa upaya, seperti Kibtyah dengan menggunakan bimbingan konseling.(Kibtyah, 2017) Dan penegakkan hukum yang berlaku. Pada hasil ini lebih memilih dengan upaya sentuhan pada hati melalui pendidikan ruhani yang di jelaskan dalam islam (mendekatkan diri kepada tuhan) agar memaksimalkan peran dari aktivasi hati, akal dan indra pada diri manusia. Sebagaimana pemaparan Abd. Aziz yang menyatakan bahwa tujuan pendidikan islam adalah mengembangkan dan mengatur tingka laku yaitu dengan mengaktifkan indra, akal dan hati.(Aziz, 2013) Hal senada juga di sampaikan oleh Subri dan Bachtiar bahwa kunci pendidikan terdapat pada pendidikan ruhani, sebagai pola menuju ketenagan dan mempererat hubungan antara manusia 
dan Allah.(Bachtiar, 2019) kunci dari beberapa pemaparan di atas adalah tentang penguatan pendidikan ruhani pada diri seseorang, agar terhindar dari maraknya penyalahgunaan narkoba.

Faktor Penghambat dalam

Menerapkan Pendidikan Ruhani di

SMK Al-Azhar Menganti Gresik

Dalam Penerapan pendidikan Ruhani di SMK Al-Azhar Menganti Gresik, terdapat beberapa hambatan yang di alami oleh pihak sekolah, beberapa faktor penghambatan dalam penerapan pendidikan ruhani di SMK Al-Azhar Menganti Gresik di sampaikan oleh Bapak. Akhmad Ikhsan, yaitu:

"Penghambat dalam menerapkan pendidikan ruhani meliputi beberapa faktor: faktor internal adalah, Kurang pahamnya guru terkait kegiatan pendidikan ruhani yang dilaksanakan oleh pihak sekolah. Faktor eksternal adalah: 1) Kurangnya pemahaman dari diri siswa terkait manfaat yang akan dirasakan ketika mengikuti kegiatan ruhani. Namun pihak sekolah terus menerus memberikan pemahaman kepada siswa 2) Kurangnya sarana prasarana seperti, tempat memadai dalam acara pagi, yaitu: saat, pembacaan sholawat burdah, sholawat nahdliyin dan sholat dhuha berjama'ah. Tapi, bagi siswa tidak menjadi penghambat signifikan dilapangan, mungkin hanya itu saja yang menjadi penghambat, karena untuk lainnya insyallah pihak sekolah meliputi kepala sekolah dan dewan guru, sudah menemukan solusi untuk megatasinya." (Wawancara, 17 Januari 2020).

Selain pemaparan dari Bapak Akhmad Ikhsan, peneliti mendapatkan pemaparan dari wakil kepala sekolah bapak Nur Qomari, tentang beberapa faktor penghambat dalam menerapan pendidikan ruhani di SMK Al-Azhar Menganti Gresik, yaitu:

"Untuk faktor penghambat adalah pada diri siswa di sekolah yang masih belum faham akan manfaat dari pendidikan ruhani. Jadi pihak guru secara terus menerus memberikan pemahaman manfaat pendidikan ruhani. Sedangakan faktor penghambat lainnya adalah dari eksternal sekolah, yaitu lingkungan, karena waktu sekolah lebih sedikit dari waktu di rumah. Maka dari itu kita pihak sekolah secara terus-menerus menguatkan kerjasama antara sekolah, orangtua dan siswa, agar siswa terpantau selama 24jam dan tidak masuk pada lubang hitam, yaitu penyalahgunaan narkoba, miras dan obat-obatan terlarang lainnya." (Wawancara, 18 Januari 2020).

Tidak, terlampau berbeda, Pemaparan tentang faktor penghambat disampaikan Bpk. Mustain, yaitu:

"Faktor penghambat dalam penerapan pendidikan ruhani pada sekolah ini, terletak pada eksternal sekolah, yaitu pada lingkungan masyarakat tempat siswa. Karena waktu lebih lama dirumah dari pada di sekolah dan banyaknya pengaruh negatif yang beragam di tengah masyarakat. Maka dari itu sekolah terus menjalin kerjasama kepada orang tua, sebagai upaya 
pencegahnnya. Selain itu terletak pada pribadi siswa, yaitu kekurang fahaman siswa, dalam menerapkan pendidikan ruhani. Sementara hanya itu yang perlu kita cari solusi."

Dari hasil pemaparan sumber data, dapat dianalisi bahwa terdapat beberapa faktor penghambat dalam penerapan pendidikan ruhani di SMK al-Azhar Menganti Gresik, pihak sekolah berusaha maksimal dalam mencari solusi terbaik dalam faktor penghambat internal dan eksternal. Sebagaimana penghambat Pada faktor internal adalah kurang fahamnya siswa tentang manfaat dari penerapan pendidikan ruhani di sekolah, dalam hal ini pihak sekolah berupaya memberikan pemahaman, melalui wali kelas dan orang tua. Sedangkan faktor penghambat eksternal yaitu lebih banyaknya waktu siswa di rumah dari pada disekolah, sedangkan pengaruh negatif di tengah masyarakat sangatlah beragam, maka dari itu solusi yang dilakukan sekolah adalah dengan memberikan pemahaman serta menjalin kerjasama dengan orangtua agar dapat memaksimalkan kinerja dari sekolah.

Sebagaimana pemaparan dari Darman, dalam bukunya yang menyatakan bahwa keterlibatan seorang pelajar dalam lingkaran penyalahgunaan narkoba, yaitu pencarian ketenangan, kurang kasih sayang, coba-coba dan lainnya (Darman, 2006). Itu ditimbulkan karena faktor keluarga, maka solusi yang diberkan adalah dengan penguatan kerjasama antara sekolah,

1 Wawancara, 18 Januari 2020 pondok pesantren, siswa dan orang tua melalui eduparenting islami, terapi dzikir dan kajian islami, yang pada dasarnya semuanya di lakukan untuk menguatkan pada pendidikan ruhani seseorang.

Sejatinya pendidikan rohani, sebagai salah satu bentuk dari pendidikan Islam (tabiyah islamiyab). Pengertian Tarbiyah Islamiyah adalah sebuah proses pendidikan yang digunakan oleh generasi yang besar kepada generasai yang lebih kecil, dengan tujuan membangunnya dengan tujuan yang baik, dengan tujuan akhir mendapatkan kemuliaan yang diberikan Allah kepadanya. Seperti contoh menguatkan keimanan kepada Allah, iman kepada malaikat Allah, iman kepada Nabi Allah, Iman kepada Kitab Allah, iman kepada hari Kiamat, iman kepada qodho dan qodar Allah. Namun pada inti keimanan adalah untuk beramal shaleh dan menjalankan metode Allah dalam beribadah tanpa mengingkari sedikitpun. Sehingga mendapatkan kebahagiaan dalam kehidupan dunia dan akhirat.(AlKattani, Dkk., n.d., pp. 20-21) Sejalan dengan Mahmud, Shaleh Abdullah menaruh pendidikan ruhani menjadi salah satu unsur dari pendidikan Islam, karena pada dasarnya pendidikan Islam meliputi: pendidikan jasmani, pendidikan ruhani dan pendidikan mental (Abdullah, 2007, p. 23).

Potensi ruhani pada diri manusia terdiri dari empat unsur yang mempunyai peran sangat penting pada diri manusia, pertama adalah roh, roh merupakan sumber dari kehidupan manusia, karena tanpa roh manusia mustahil dapat hidup. Kedua adalah hati, hati merupakan pemberian Allah 
yang teramat istimewa, karena hati merupakan sentral dari awal perbuatan yang akan di lakukan oleh manusia, karena hati mampu melihat hakikat dari kebenaran. Hal inilah yang membadakan antra hati dan akal (Cholik, 2015). Ketiga adalah akal, keberadaan akal sebagai tumpuan dalam menerima ilmu pengetahuan yang bermanfaat. Akal juga yang nantinya mendorong manusia mampu berfikir kritis dalam memecahkan permasalahan.(Aziz, 2013) Keempat adalah nafsu, yang dimaknai dengan hasrat, kamuan, atau dorongan dalam melakukan perbuatan baik maupun buruk. Sedangkan Al-Ghazali memaknai nafsu dalam melakukan sesuatu pasukan dari hati yang halus, karena peran hati sebagai awal penggerak dari kemauan manusia (Fahmi, 2016).

Memoinjam pemaparan Syafe'i yaitu tujuan dari pendidikan ruhani pada tingkat pelajar, adalah (Imam Syafe'I: ${ }^{2015)}$ : Meningkatkan keimanan kepada Allah SWT. Sehingga manusia benar-benar menerima ajaran islam, tentu akan menerima seluruh cita-cita ideal yang ada di Al-Qur'an dan Hadis, Mengajarkan ibadah yang benar, Mempunyai budi pekerti yang baik, Mempunyai akhlak mulia serta menerapkan dalam kehidupan seharihari, Pemurnian dan pensucian diri secara individual dan kelompok, dari sifat-sifat negatif yang lebih sering di ikuti oleh nurani manusia dan yang terpenting adalah agar pelajar mampu mengarahkan hawa nafsu dalam hal kebaikan dan ketaan kepada Allah. Disaat ada yang melihat ataupun tidak (Al-Kattani, Dkk., n.d., p. 38).

\section{KESIMPULAN}

Berdasarkan hasil penelitian tentang revitalisasi pendidikan ruhani dalam mencegah penyalahgunaan narkoba pada pelajar di SMK Al-Azhar Menganti Gresik, yang diawali dari mencari ketenagan, broken home, dan beberapa faktor lain. Peneliti mendapatkan sebuah temuan baru, bahwa dalam mencegah tidak hanya dengan hukuman, namun perlu menguatkan pendidikan ruhani melalui beberapa pendekatan keagamaan kontemporer, seperti penguatan kolaborasi dengan pondok pesantren melalui kajian-kajian fikih islam, agenda pagi hari dimulai dengan sholawat, dzikir, istighosah, sholat dhuha dan tausiyah guna aktivasi hati, akal dan indra (HAI) dibingkai dengan tema "mengetuk pintu langit", serta penguatan kerjasama dengan orangtua melalui eduparenting. Serta adanya beberapa faktor penghambat dalam penerapan pendidikan ruhani, seperti faktor internal kekurang fahaman siswa tentang manfaat dari pendidikan ruhani dan faktor ekternal siswa berupa pengaruh negatif di tengah masyarakat. Sudah dapat dicegah dengan beberapa kegiatan pendidikan ruhani melalui pendekatan keagamaan kontemporer.

\section{REFERENSI}

Abdullah, S. (2007). Teori-Teori Pendidikan Berdasarkan Al-Qur'an (Cet. Ke-4). Cipta Karya.

Al-Kattani, Dkk., A. H. (n.d.). Pendidikan Rubani Terjemah At- 
Tarbiyah Ar-Rubiyah (Cet. Kedua, 2010). Gema Insan Press.

Amriel, R. I. (2007). Psikologi Kaum Muda Pengguna Narkoba (Edisi Pertama). Salemba Humanika.

Arif, M. (2018). Revitalisasi Pendidikan Cinta Tanah Air di Pondok Pesantren Darul Ihsan Menganti Gresik. Jurnal Iqra' : Kajian Ilmu Pendidikan, Vol. 3(No. 2), 277-296. https://doi.org/https://doi.org /10.25217/ji.v3i2.369

Arif, M., \& Sulistianah, S. (2019). Problems in 2013 Curriculum Implementation for Classroom Teachers in Madrasah Ibtidaiyah. 6(1), 110-123. https://doi.org/10.24235/al.ibti da.snj.v6i1.3916

Aziz, A. (2013). Hakikat Manusia dan Potensi Ruhaninya dalam Pendidikan Islam: Sebuah Kajian Ontology. Ta'allum: Jurnal Pendidikan Islam, 1(2), 223-233.

Aztri, S., \& Milla, M. N. (2013). Rasa berharga dan pelajaran hidup mencegah kekambuhan kembali pada pecandu narkoba studi kualitatif fenomenologis. Jurnal Psikologi, 9(1), 48-63.

BNN: Sepanjang Tabun 2018, Mayoritas Pengguna Narkoba Adalab Generasi Muda. (n.d.). Tribunnews.com. Retrieved May 15, 2019, from http://www.tribunnews.com/na sional/2018/12/20/bnnsepanjang-tahun-2018mayoritas-pengguna-narkobaadalah-generasi-muda

Cholik, A. A. (2015). Relasi Akal dan Hati menurut al-Ghazali. Journal Kalimah, 13(2), 287-310.
Darman, F. (2006). Mengenai Jenis dan Efek Buruk Narkoba. Visi Media.

Emdad-ul Haq, M. (2010). Drugs in South Asia From the Opium Trade to the Present Day (2nd Edition). Palgrave.

Fahmi, M. (2016). Nalar Kritis Terhadap Konsep Nafsu AlGhazali. AT-TURAS: Jurnal Studi Keislaman, 3(2), 175-187.

Faisol. (n.d.). Pendidikan Islam Perspektif (2017th ed.). Guepedia.

Kibtyah, M. (2017). Pendekatan bimbingan dan konseling bagi korban pengguna narkoba. Jurnal Ilmu Dakwah, 35(1), 52-77.

Okezone. (n.d.). 5,9 Juta Anak Indonesia Jadi Pecandu Narkoba: Okezone News. https://news.okezone.com/. Retrieved May 26, 2019, from https://news.okezone.com/read /2018/03/06/337/1868702/59-juta-anak-indonesia-jadipecandu-narkoba

Qomar, M. (2013). Epistimologi Pendidikan Islam Dari Metode Rasional Hingga Metode Kritik. Erlangga.

Rahmadona, E., \& Agustin, H. (2014). Faktor yang berhubungan dengan penyalahgunaan narkoba di rsj prof. hb. sa'anin. Jurnal Kesehatan Masyarakat Andalas, 8(2), 60-66.

Sanger, E. (2013). Penegakan Hukum Terhadap Peredaran Narkoba Di Kalangan Generasi Muda. Lex Crimen, 2(4).

Stapa, Z., Yusuf, N., \& Shaharudin, A. F. (2012). Pendidikan Menurut Al-Quran dan Sunnah Serta Peranannya Dalam Memperkasakan Tamadun 
Ummah (Education According to Al-Quran and Sunnah and Its Role in Strengthening the Civilization of Ummah). Jurnal Hadhari: An International Journal, $7-22$.

Subri, \& Bachtiar, A. (2019). Pendidikan Ruhani Dalam Alquran. Intiqad: Jurnal Agama Dan Pendidikan Islam, 11(1), 171191.

Sugiyono. (2010). Metode Penelitian Pendidikan Pendekatan Kuantitatif, Kualitatif dan R\&D. Alfabeta.

Sugiyono. (2016a). Memabami Penelitian Kualitatif (Cetakan ke Duabelas). Alfabeta.

Suryadi, R. A. (2018). Ilmu Pendidikan Islam. Budi Utama.

Syafii, A. (2009). Pengaruh Narkoba Terhadap Kenakalan Remaja di Sulawesi Tengah. Media Litbang Sulawesi Tengah, 2(2).

Taringan, I. J. (n.d.). Peran Badan Narkotika Nasional, dengan Organisasi Sosial Kemasyarakatan dalam Penanganan Pelaku Penyalagunaan Narkotika (2017th ed.). Deepublish.

Wijaya, H. (2018). Analisis Data Kualitatif Ilmu Pendidikan Teologi. Sekolah Tinggi Teology Jaffray.

Zuhri. (2016b). Cognitivergentive Desaind Kurikulum Pendidikan Pesantren (Konsepsi dan Aplikasinya). Budi Utama. 